\title{
Construction of Practical Teaching System of Measurement \& Control Technology and Instrument Major based on CDIO Engineering Education Mode
}

\author{
Wu Haiyun, Wei Yong*, Du Yanhong, Liu Yuan \\ College of Engineering and Technology \\ Tianjin Agricultural University \\ Tianjin, China \\ haiyunwu2013@163.com
}

\author{
Guo Xiaoying \\ College of Water Conservancy Engineering \\ Tianjin Agricultural University \\ Tianjin, China \\ 463546849@qq.com
}

\begin{abstract}
In order to educate engineers with strong ability in engineering practices, the practice teaching reform of Measurement \& Control Technology and Instrument specialty was introduced under the guidance of CDIO engineering education idea. The practical teaching system was reconstructed in many aspects. Firstly, a multidimensional progressive experimental teaching system was established. And then, an interactive practical teaching platform was built. The concrete measures of teaching reform of integrated curriculum design were explored in detail. At last, a new assessment model under the guidance of CDIO concept was put forward. This paper explored the CDIO engineering education idea in solving the role of practical teaching problems in Measurement \& Control Technology and Instrument professional degree undergraduate students, which can provide certain reference to the cultivation of practical engineering undergraduate under complex requirements.
\end{abstract}

Keywords-CDIO; practical teaching; engineering education; reform

\section{INTRODUCTION}

CDIO(conceive, design, implement and operate) was a new engineering education idea created by four universities in the United States, which were MIT, Royal Institute of Technology, Chalmers University of Technology, and Linköping University. The corresponding international cooperation organization was established at four years later in 2004 [1-2]. CDIO initiative was an innovative educational framework for producing the next generation of engineers.

There was a clear difference between CDIO education model and traditional classroom education. The basic link of CDIO was to conceive, design, implement and operate, so that students can learn engineering with an organic link between initiative, practice and curriculum. Practice teaching was an important component of undergraduate teaching, and it was the necessary link of Measuring \& Control Technology and Measurement major to train students' innovative spirit and engineering practice ability.

Project of Teaching Quality and Teaching Reform of Undergraduate Education in Tianjin Ordinary Higher Education Institutions(171006101C); Innovation and Entrepreneurship Training Reform Model Projects of Tianjin Agricultural University $(20170416,20170813)$
In CDIO engineering education mode, teachers were considered as the guidance and students as the center for practical teaching system of Measurement \& Control Technology and Instrument specialty [3]. Based on the study of the theory, the goal of CDIO was to cultivate students' practical ability and innovation ability. It was focus on students' practical skills, scientific thinking, team consciousness and the cultivation of innovation spirit, which was called "interactive teaching". Students' innovation ability and the ability of sustainable development would be improved by the way.

\section{CONTENT OF PRACTICE TEACHING}

Aiming at training students' comprehensive application ability and practical ability, practical teaching system was consisted of five parts, namely, independent course experiment, curriculum design, practice teaching, project training and graduation design. It was composed of relative independent sets of practical links, and was characterized by the practice of education from cognition, operation to comprehensive innovation.

The independent course experiment and course design practice could be used to deepen theoretical study and improve practical skills. The basic design, operation, operation and maintenance and other aspects of the training were conducted through practice, project training and other practice. Students' comprehensive ability would be trained through comprehensive training and graduation design, etc. Electronic design contest, college of science and technology innovation and practice innovation training extracurricular practice were took as the main channel to improve the students' practical ability.

There were the main practice courses: University Physics experiment, Circuit Principle experiment, experiment of Digital Electronic Technology, Analog Electronic Technology experiment, Metalworking Practice, Electronic Circuit, CAD, DSP experiment, Embedded System Design and Development Practice, Simulation of Virtual Instrument practice, Digital Image Processing, C Program design, Application of Microprocessor experiment, Detection Technology and Intelligent Instrument Project training, EDA project training, 
Sensor and Detection Technology of Electronic Integrated training, Professional Basic Ability training, Production Practice of Measuring and Controlling Instrument, Measurement \& Control Course Design :

\section{(1) Measurement \& Control Course Design}

(2) Graduation Practice, Graduation Design and Graduation Thesis.

\section{IMPLEMENTATION OF PRACTICE TEACHING IN CDIO ENGINEERING MODE}

\section{A. Construction of Multidimensional Progressive Practice Teaching System}

The traditional practice training environment was mainly based on teacher's one-way knowledge transfer and students' passive acceptance. Students were satisfied with imitative practice, and they were weak in active participation in exploration and practice. Thus the innovative spirit and practical ability were difficult to train effectively.

Based on the engineering characteristics, multidimensional practice teaching system was horizontal expansion from four dimensions of progressive experimental system, professional training, competition, project practice, and distribution to the undergraduate four years a total of eight semesters. The practical teaching linked of several dimensions coordinated and complemented each other, and constructed a multidimensional practical teaching system covering the first and second classes effectively.

The progressive experimental teaching system was composed of three progressive levels: basic experiment, comprehensive experiment and general simulation experiment. In the construction of experimental teaching system, a relationship of "basic, professional, integrated and applied" was used as its main line. The related courses were organic connection without overlapping. Through continuous exploration and optimization of the content and system of practice teaching, a set of effective and progressive experimental teaching system based on integration of light, machine, electricity and computer with its own characteristics has been constructed, which was showed in Fig. 1

\section{1) Basic experiment}

Three echelons were reflected in each experiment: basic, design and innovation type. The first two was required, and after was a selected. The experiment content was used to help students to deepen the theoretical teaching content and some theoretical understanding of the mechanism. It could also be used to train students of all kinds of basic experimental instruments and experimental equipment operation skills, that help student to master experimental method, cultivate students' ability to identify problems to solve problems, establish the basic professional quality, stimulate students' professional interests, and to get the initial formation of a good occupation habit.

\section{2) Comprehensive experiment}

Comprehensive experiment was composed of three modules: basic skills experiment, design experiment and comprehensive course experiment. Among them, several integrated curriculum design were involved in each module. The courses were set up in the 3-6 semester, and each course was divided into two weeks.

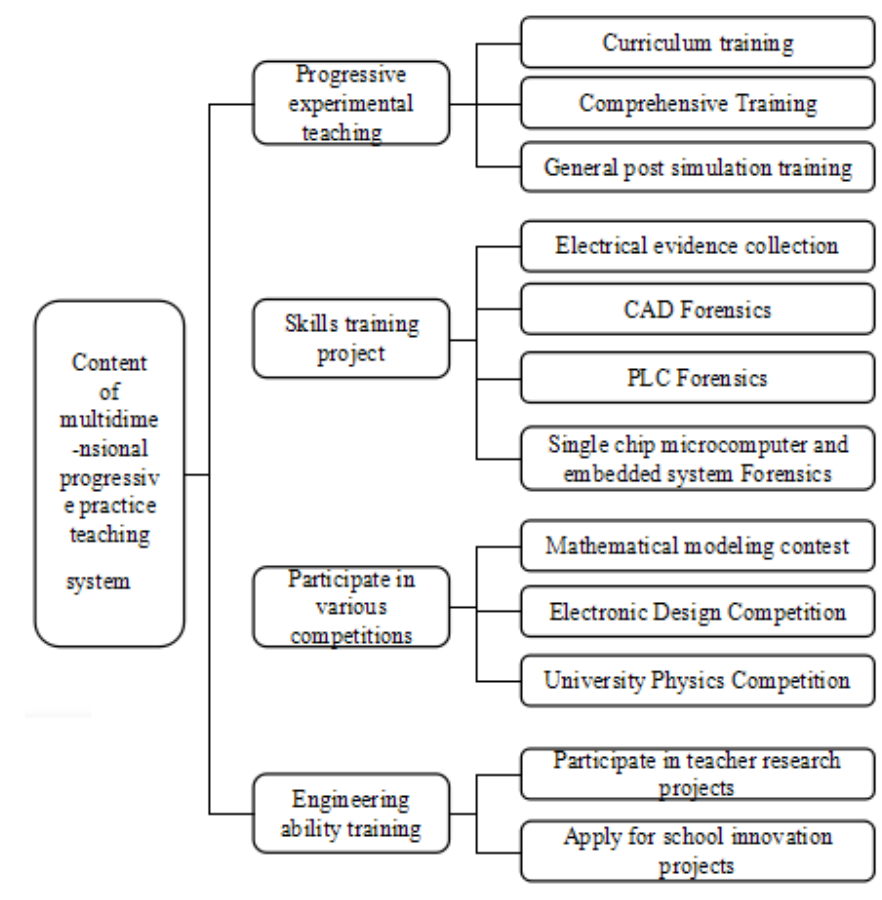

Fig. 1. Construction of multidimensional progressive practice teaching system

Each module of the layer was a comprehensive training for several key courses. And there was a horizontal connection and progressive relation among modules. Students' ability training of organization, application, integration, innovation and research through the experimental course could enable students to combine with professional knowledge and practice, which focused on cultivating the students' ability of flexible use of knowledge, theory and practice, improve their professional skills.

\section{3) General post simulation experiment}

General post simulation experiment was set up in the seventh semester, and lasted for three weeks. It was a kind of practice teaching which aimed at industry and project oriented in simulation. It was not only a big exercise before graduation, but also a comprehensive exercise before the job. Through the "enterprise management, project operation" model, students would be trained in professional core knowledge, skills and professional key competencies. It can help students to complete role change as soon as possible after graduation.

\section{B. Construction of Interactive Practice Platform}

The "interactive" practice was a bidirectional relationship between teachers and students, students and students. "Interactive" practice environment was an important platform of theory and practice integrating. The interactive practice platform was shown in Fig.2. There was two parts in the platform: the independent research practical teaching instrument and the students' free studio and open laboratory. The interactive practice environment, which could be used to carry out experiments and innovative experiments, provided a 
flexible study mode of found the problem, and solve the problems for students to students, and teachers to students.

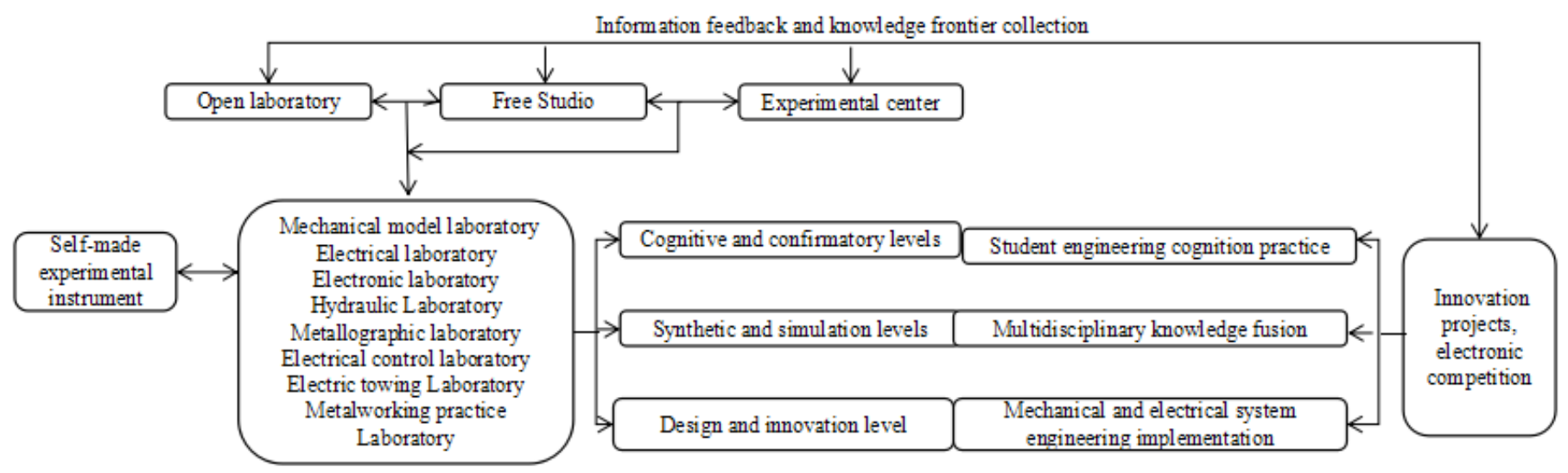

Fig. 2. Interactive practice platform

\section{Implementation of Integrated Curriculum Design in CDIO Engineering Model}

The traditional curriculum design was usually subordinate to one course, and the connection between different courses was poor. Students were usually confined to one course of design. The thinking model designed by the students was a fixed pattern reference design with the "reference design guide book and manual", and the result of the exercise was often a mere formality. Thus, integrated electromechanical curriculum design aiming at the training of engineering practice ability was putted forward under the guidance of $\mathrm{CDIO}$ engineering education idea.

The integrated curriculum design of Measurement \&Control Technology and Instrument major was not subjected to any course design. While the theoretical knowledge covered in the course design was include the Principles and Applications of Sensors, the Theory of Measurement and Control Circuit, the Principle of Single Chip Microcomputer, the Principle and Design of Measurement and Control System and other specialized courses. Because of its strong engineering practice, integrated curriculum design was especially in line with the CDIO engineering education concept advocated "learning by doing" and "project based education and learning".

With the CDIO concept as a guide, instead of traditional decentralized teaching mode, comprehensive curriculum design took centralized teaching mode [4]. It selected a group as a unit, including a survey, design, implementation, and finally, each design team focused on defense. Three or four students form a team to collaborate with each other and complete projects with practical engineering background. It enable students to systematically carry out the overall training of ideas, designs, implementations, and operations advocated by the CDIO engineering education philosophy. It also could be used to deepen students' understanding of the theoretical knowledge, improve students' practical ability, arouse students' subjective initiative, train students' innovative ability, and then enhance their self-confidence [5].

\section{Practice teaching assessment mechanism}

The curriculum evaluation in universities usually carried out the hundred percent system and the five grade system which was shown in Table I [6-8]. While the enterprise product quality and its service standards were implemented in a stricter two grade system. This difference has increased the difficulty of transforming students into enterprise employees, which was one of the important factors that lead to the difficulty of students' employment and the high cost of enterprise retraining. A new assessment model under the guidance of CDIO concept was putted forward, which was shown in Table II.

TABLE I. TRADITIONAL FIVE GRADE SYSTEM

\begin{tabular}{|c|c|c|}
\hline Number & Grade & Score segment \\
\hline 1 & Excellent & $90-100$ \\
\hline 2 & Good & $80-89$ \\
\hline 3 & Secondary & $70-79$ \\
\hline 4 & Pass & $60-69$ \\
\hline 5 & Fail & $<60$ \\
\hline
\end{tabular}

TABLE II. NEW ASSESSMENT MODEL UNDER CDIO

\begin{tabular}{|c|c|c|c|}
\hline \multirow{2}{*}{ Contents } & \multirow{2}{*}{$\begin{array}{c}\text { paper-based } \\
\text { exam }\end{array}$} & $\begin{array}{c}|c| \\
\text { Project practice } \\
\text { technical report }\end{array}$ & $\begin{array}{c}\text { Project practice } \\
\text { demonstration }\end{array}$ \\
\cline { 3 - 4 } Proportion & $35 \%$ & $30 \%$ & $35 \%$ \\
\hline
\end{tabular}

\section{CONCLUSION}

The reform of CDIO engineering education practice teaching system under Measurement \& Control Technology and Instrument specialty was proposed. It was hoped that the single mode of practice teaching through reforms to break the traditional decentralized, better integration idea of "conceive, design, implement and operate". At the same time, through the practice teaching, it enabled students to have the ability of certain creativity, initiative and variety. What's more, to improve students' practical ability and theoretical application ability, to provide students with an analysis, research, design, solve practical projects a series of more complete learning and 
practice process. Finally, through the practice of teaching reform, students became the leading role in practical teaching activities, while teachers played a guiding role in teaching activities.

\section{ACKNOWLEDGMENT}

This research was funded by the Project of Teaching Quality and Teaching Reform of Undergraduate Education in Tianjin Ordinary Higher Education Institutions (171006101C); and the Innovation and Entrepreneurship Training Reform Model Projects of Tianjin Agricultural University (20170416, 20170813).

\section{REFERENCES}

[1] J. Bai, L. Hu, Y Li, Z. Tian, L. Xie, L. Wang, M. Zhou, J. Guan, and H. $\mathrm{Xie}$, "The progress of CDIO engineering education reform in several China universities: A review," Procedia-Social and Behavioral Sciences, 2013, vol. 93, pp. 381-385.

[2] C. Norrman, D. Bienkowska, M. Moberg, and P. Frankelius, "Innovative methods for entrepreneurship and leadership teaching in CDIO-based engineering education," The proceeding of 10th International CDIO Conference, 15-19 June 2014, Barcelona, Spain.

[3] G. Yang, R. Gao, "Thought on Experimental Teaching Reform in Higher School in New Position," Research in Teaching, 2005, vol. 28, pp. 34-40. (In Chinese)

[4] Y. Huang, M. Li, and Y. Ren, "Construction of outstanding PE teacher training mode of based on CDIO," Agro Food Industry Hitech, 2017, vol. 28, pp. 3141-3145.

[5] M. S. Kim, "Development and effect of a Web- based problem- based learning system for an accounting course in engineering education," World Transactions on Engineering and Technology Education, 2016, vol. 14, pp. 394-403.

[6] E. Sayrol, R. Bragos, E. Alarcon, "Mixed Integration of CDIO skills into Telecommunication Engineering Curricula," 2015, vol. 102, pp.127-130.

[7] Y. Q. Li, "An investigation on current situation of teachers information teaching ability of Normal University Internet plus background," China University Teaching, 2016, vol. 7, pp. 87-91.

[8] Z. G. Zhang, L. P. Xiang, S. A. Zhang, "On the new mode of eminent and technical talents cultivation based on CDIO," Journal of Anhui University of Technology (Social Sciences Edition), 2012, vol. 29, pp. 104- 105. 